\title{
The influence of feeding rapeseed cake and extruded soyabean on the performance of lactating cows and the fatty acid pattern of milk*
}

\author{
V. Kudrna ${ }^{1}$ and M. Marounek ${ }^{1,2,3}$ \\ ${ }^{1}$ Research Institute of Animal Production \\ Prague 10, CZ-104 01, Czech Republic \\ ${ }^{2}$ Institute of Animal Physiology and Genetics, Academy of Sciences of the Czech Republic \\ Prague 4, CZ-142 20, Czech Republic
}

(Received 19 September 2005; revised version 15 February 2006; accepted 5 July 2006)

\begin{abstract}
Twenty-seven Holstein cows were fed total mixed rations (TMR) supplemented with protected palm fat (PPF), rapeseed cake (RC) or extruded soyabean (ESB) for 14 weeks. Feed intake and milk yield were recorded. Samples of milk were taken weekly and analysed. Jugular blood was taken three times two hours after feeding. Cows of the PPF group consumed significantly less feed and produced more milk than cows of the RC and ESB groups $(32.9,31.7$ and $30.7 \mathrm{~kg}$ fat-corrected milk/d, respectively). Milk fat from cows fed diets supplemented with RC and ESB contained more stearic, vaccenic and conjugated linoleic acids, and less palmitic acid than milk fat of cows fed the PPF diet $(\mathrm{P}<0.05)$. The content of polyunsaturated fatty acids (PUFA) in milk fat of cows fed ESB was higher, and the atherogenicity of its fatty acids, lower than in milk fat of other cows. This was, however, accompanied by lower oxidative stability of milk fat. Supplementation of TMR with RC increased the spreadability index of manufactured butter $(\mathrm{P}<0.025)$. Both milk and blood urea concentrations were significantly lower for cows fed the ESB diet. This suggests that crude protein in this diet was less degradable than in other diets. Body weights of cows on diets RC and ESB increased by 11.3 and $15.6 \mathrm{~kg}$, respectively, whereas the body weight of cows on the PPF diet decreased by $1.7 \mathrm{~kg}$, on average. It can be concluded that feeding oilseed-based supplements to dairy cows decreased milk yield and milk production efficiency somewhat, but improved the nutritional quality of milk fat.
\end{abstract}

KEY WORDS: milk yield, milk fat, fatty acids, oilseeds, soyabean

\footnotetext{
* Supported by the Ministry of Agriculture of the Czech Republic, Project MZe 0002701403

${ }^{3}$ Corresponding author: e-mail: marounek@iapg.cas.cz
} 


\section{INTRODUCTION}

Recent research has focused on dietary modification of milk fat to achieve better nutritional quality, particularly by increasing the unsaturated fatty acid (UFA) concentration, adjusting the n-6/n-3 ratio of polyunsaturated fatty acids (PUFA), and increasing the conjugated linoleic acid (CLA) content. Supplementation of diets for dairy cows with oilseeds represents a means by which the milk-fat fatty acid (FA) profile may be modified. Oilseeds seem to be a better alternative than the corresponding refined oils, as seeds also contain valuable protein and the seed coat provides partial protection of UFA from ruminal biohydrogenation. In recent years, rapeseed in the form of meal or cakes with varying fat contents has become a common component of dairy cow diets. Soyabean is frequently fed to dairy cows as well. The lipids of rapeseed and soyabean are highly unsaturated, with oleic and linoleic acids as the principal components, respectively (Chouinard et al., 1997; McNamee et al., 2002). Feeding diets containing thermally treated whole soyabean offers some advantages over non-treated soyabean. Extrusion of whole soyabean decreases protein degradation in the rumen and increases amino acid flow to the duodenum. Consequently, more amino acids are absorbed in the intestine (Stern et al., 1985). Other oilseeds used in the feeding of a dairy cow include linseed, sunflower seed and lupine seed (review by Chilliard and Ferlay, 2004).

The purpose of the present experiment was to compare the effect of including rapeseed cake and extruded soyabean on the performance of high-yielding dairy cows, and on the composition of milk. Dairy products provide a significant part of the overall saturated fat consumed by man. This fact makes them the preferential target of criticism by dieticians. Thus, attention has been focused on the effects of dietary treatments on those parameters of milk fat composition related to human health. Contemporary analytical techniques allow identifying and quantifying tens of FA. To simplify evaluation of results, several indexes summarizing various effects of different FA were calculated.

\section{MATERIAL AND METHODS}

\section{Animals and diets}

Twenty-seven multiparous Holstein cows, 38-45 days postpartum were assigned to one of three total mixed rations (TMR) on the basis of daily milk yield, body weight (609 $\mathrm{kg}$ on average) and days in milking. The rations were formulated to be almost isonitrogenous and equal in energy content. The TMR contained the same amounts of silaged maize cobs, lucerne and sugar beet pulp, 
lucerne hay and brewery grain, but different amounts of maize (grain), ground wheat and extracted soyabean meal (Table 1). The first TMR was supplemented

Table 1. Ingredients and chemical composition of diets supplemented with protected palm fat (PPF), rapeseed cake (RC) and extruded soyabean (ESB)

\begin{tabular}{|c|c|c|c|}
\hline \multirow{2}{*}{ Item } & \multicolumn{3}{|c|}{ Diet } \\
\hline & PPF & $\mathrm{RC}$ & ESB \\
\hline \multicolumn{4}{|l|}{ Ingredients, $\% D M$} \\
\hline maize cobs, silage & 19.3 & 19.1 & 19.2 \\
\hline lucerne, silage & 29.2 & 29.0 & 29.0 \\
\hline sugarbeet pulp, silage & 4.5 & 4.5 & 4.5 \\
\hline lucerne hay & 3.8 & 3.8 & 3.8 \\
\hline brewery grain & 3.3 & 3.3 & 3.3 \\
\hline maize (grain) & 14.0 & 12.6 & 8.6 \\
\hline wheat, ground & 8.9 & 4.1 & 16.1 \\
\hline soyabean meal, extracted & 13.5 & 3.9 & 3.6 \\
\hline extruded soyabean & - & - & 10.8 \\
\hline rapeseed cake & - & 19.2 & - \\
\hline Megalac $^{\mathrm{TM}}$ & 2.5 & - & - \\
\hline vitamin supplement $^{1}$ & 0.8 & 0.3 & 0.7 \\
\hline sodium bicarbonate & 0.2 & 0.2 & 0.2 \\
\hline limestone & - & - & 0.2 \\
\hline \multicolumn{4}{|l|}{ Nutrients, $\% D M$} \\
\hline crude protein & 17.7 & 17.0 & 16.6 \\
\hline $\mathrm{PDIN}^{2}$ & 11.2 & 10.9 & 10.9 \\
\hline PDIE $^{3}$ & 10.8 & 10.1 & 10.7 \\
\hline crude fat & 5.4 & 5.7 & 5.4 \\
\hline NDF & 31.8 & 34.8 & 34.4 \\
\hline $\mathrm{ADF}$ & 23.7 & 24.8 & 24.6 \\
\hline $\mathrm{Ca}$ & 0.93 & 0.67 & 0.76 \\
\hline $\mathrm{P}$ & 0.50 & 0.52 & 0.47 \\
\hline $\mathrm{NEL}, \mathrm{MJ} / \mathrm{kg}^{4}$ & 7.7 & 7.5 & 7.5 \\
\hline \multicolumn{4}{|c|}{$\begin{array}{l}{ }^{1} \text { Vitamix S2 (Biofaktory Ltd., Prague) contained per } 1 \mathrm{~kg}, \mathrm{~g}: \mathrm{Ca} 105, \mathrm{P} 85, \mathrm{Na} 95, \mathrm{Mg} 70, \mathrm{Z} \\
\mathrm{Mn} 1.5, \mathrm{Cu} 0.51 \text {; vit. E } 0.65 ; \mathrm{mg} \text { : Se } 80 ; \mathrm{IU} \text { : vit. A } 570000 \text {, vit } \mathrm{D}_{3} 68000 \\
{ }^{2} \text { protein digested in the small intestine supplied by rumen-undegraded protein and microbial } \\
\text { protein from rumen-degraded protein } \\
3 \text { protein digested in the small intestine supplied by rumen-undegraded protein and microbial } \\
\text { protein from rumen-fermented organic matter } \\
{ }^{4} \text { calculated from the ingredient composition }\end{array}$} \\
\hline
\end{tabular}

with Megalac ${ }^{\mathrm{TM}}$, which is protected palm fat (PPF) produced by Agro-Best Ltd. Běstovice (Czech Republic). Megalac ${ }^{\mathrm{TM}}$ consists of calcium salts of fatty acids. The product contains fat and $\mathrm{Ca}$ at 76 and $9 \%$, respectively. The second TMR was supplemented with rapeseed cake (RC) containing $15.9 \%$ crude fat, and the 
third TMR, with soyabean, extruded at $130^{\circ} \mathrm{C}$, containing $19.3 \%$ crude fat (ESB). The principal fatty acids in these supplements are palmitic, oleic, and linoleic acids, respectively. The animals were housed in a free-stall barn and fed using the INSENTEC system for individual roughage intake control by Insentec B.V. (Marknesse, Holland). Cows were fed ad libitum. The experiment lasted 14 weeks.

\section{Sampling and measurements}

Feed intake was recorded electronically. Samples of feeds were taken once a fortnight. Milk production was recorded at each of two milkings daily. Samples of milk were taken weekly, i.e. 14 milk samples per cow were obtained. Milk was treated with Broad Spectrum Microtabs ${ }^{\circledR}$ II preservative (D \& F Control Systems Inc., Son Ramon, USA). Blood was sampled three times in the course of the experiment, on days 82,110, and 131 of lactation, two hours after the morning feeding. Cows were weighed in two-week intervals.

Analyses

Feeds were oven-dried at $105^{\circ} \mathrm{C}$ to a constant weight. Protein and fat concentrations were determined employing a Kjeltec Auto 1030 Analyser and a Soxtec 1043 from Tecator Comp. (Sweden), respectively. Fibre fractions were determined according to Van Soest et al. (1991) using a Fibertec 2010 from the same company. Calcium and phosphorus in feeds were determined by atomic absorption spectrometry using a Perkin Elmer 5000 instrument and a molybdovanadate reagent, respectively, after ashing of dry samples. Milk fat, crude protein and lactose were determined in a commercial laboratory using a Bentley 2500 analyser (Bentley Instruments Inc., Chaska, USA). Milk urea was assayed colorimetrically, after reaction with $p$-dimethylaminobenzaldehyde (Gajdůšek et al., 1996).

Lipids from feeds were extracted with a mixture of chloroform and methanol (2:1). The solvent was evaporated under vacuum. Milk fat was extracted with diethylether and petrolether (1:1), according to ISO 1211. Alkaline transmethylation of fatty acids present in extracts was carried out according to ISO 5509. Gas chromatographic analysis of the methyl esters was performed using a Hewlett-Packard 5890 gas chromatograph equipped with a programmed $60 \mathrm{~m}$ HP-Innowa capillary column $\left(180-240^{\circ} \mathrm{C}\right)$ and a FI detector.

\section{Calculations}

The index of atherogenicity was calculated according to the following equation (Chilliard and Ferlay, 2004): 


$$
\mathrm{AI}=(\mathrm{C} 12+4 \times \mathrm{C} 14+\mathrm{C} 16) / \text { sum of UFA }
$$

The index of peroxidisability (indicator of oxidative stability) was calculated according to Castellini et al. (2000):

$$
\text { PI }=0.025 \times \text { Mono }+ \text { Di }+2 \times \text { Tri }+4 \times \text { Tetra }+6 \times \text { Penta }+8 \times \text { Hexa }
$$

where Mono, Di, Tri, Tetra, Penta and Hexa represent weight percentages of monoenoic, dienoic, trienoic, tetraenoic, pentaenoic and hexaenoic FA, respectively.

The index of desaturation was calculated using equation of Chilliard and Ferlay (2004):

$$
\mathrm{DI}=\mathrm{C} 18: 1 \mathrm{n} 9 \mathrm{c} /(\mathrm{C} 18: 0+\mathrm{C} 18: 1 \mathrm{n} 9 \mathrm{c})
$$

The index of spreadability of manufactured butter was calculated according to Timmen (1990):

$$
\mathrm{SI}=\mathrm{C} 18: 1 \mathrm{n} 9 \mathrm{c} / \mathrm{C} 16: 0
$$

Data were statistically analysed by one-way analysis of variance using the GLM procedure of SAS, version 8.2 (SAS Institute, Cary, NC, USA). In the case of a significant difference $(\mathrm{P}<0.05)$ groups were compared by Tukey's test. Some extreme values were excluded on the basis of Dixon's test.

\section{RESULTS}

The nutrient composition of diets is shown in Table 1. All diets were similar in their contents of crude protein, fat, ADF and energy. The NDF content was

Table 2. Fatty acid profile ${ }^{1}$ of diets supplemented with protected palm fat (PPF), rapeseed cake (RC) and extruded soyabean (ESB)

\begin{tabular}{lrrr}
\hline \multirow{2}{*}{ Fatty acids } & \multicolumn{3}{c}{ Diet } \\
\cline { 2 - 4 } & PPF & RC & ESB \\
\hline MCFA (<C 15) & 1.33 & 1.27 & 1.28 \\
Palmitic (C 16:0) & 25.01 & 23.05 & 24.13 \\
Stearic (C 18:0) & 4.47 & 4.31 & 4.40 \\
Oleic (C 18:1) & 21.13 & 25.31 & 20.28 \\
Linoleic (C 18:2) & 33.88 & 31.03 & 35.50 \\
$\alpha$-Linolenic (C 18:3) & 5.43 & 5.68 & 5.71 \\
Arachidic (C 20:0) & 0.98 & 1.03 & 0.91 \\
Behenic (C 22:0) & 2.37 & 2.37 & 2.35 \\
Lignoceric (C 24:0) & 1.02 & 1.01 & 1.00 \\
Other acids & 4.38 & 4.94 & 4.44 \\
Total SFA & 36.44 & 34.29 & 35.38 \\
Total UFA & 63.56 & 66.09 & 64.62 \\
\hline
\end{tabular}

${ }^{1}$ expressed in $\mathrm{g}$ per $100 \mathrm{~g}$ of fatty acids determined

lower in the PPF diet by 3.0 and 2.6 percentage units than in diets RC and 
ESB, respectively. The former diet contained more $\mathrm{Ca}$, presumably because Megalac ${ }^{\mathrm{TM}}$ contains Ca-salts of palm oil FA. Diets differed in their UFA/SFA ratios, which were $1.74,1.93$ and 1.83 in diets $\mathrm{PPF}, \mathrm{RC}$, and $\mathrm{ESB}$, respectively (Table 2). The intake of dry matter was significantly lower in cows on diet PPF $(\mathrm{P}<0.01)$ than in cows of other groups (Table 3$)$. Consequently, also intake of nutrients (except $\mathrm{Ca}$ ) was lower in PPF-fed cows. These cows decreased their body weight by $1.7 \mathrm{~kg}$, on average, whereas cows in groups RC and ESB gained 11.7 and $15.6 \mathrm{~kg}$, respectively, in the course of the trial. Nonetheless, the yield of fat-corrected milk and the concentration of milk fat were higher in PPF-fed cows than in the other cows: significantly in comparison with cows fed ESB $(\mathrm{P}<0.05)$ and in tendency with those fed RC. Milk urea was significantly lower in cows fed ESB than in cows fed PPF and RC $(\mathrm{P}<0.01)$. Also blood urea was lower in these cows than in ones fed diets with PPF and RC: $196 \mathrm{mg} \mathrm{N} / 1$ vs 231 and $237 \mathrm{mg} \mathrm{N} / 1$ $(\mathrm{P}<0.025)$. Other blood parameters were not significantly affected.

Table 3. Initial and final weight of cows, intake of feed dry matter, milk production and milk composition for cows supplemented with protected palm fat (PPF), rapeseed cake (RC) and extruded soyabean (ESB)

\begin{tabular}{lcccc}
\hline \multirow{2}{*}{ Item } & \multicolumn{3}{c}{ Diet } & \multirow{2}{*}{ SEM } \\
\cline { 2 - 4 } & PPF & RC & ESB & \\
\hline Initial weight, kg & 596.1 & 603.0 & 629.0 & 30.1 \\
Final weight, kg & 594.4 & 614.7 & 644.6 & 28.2 \\
Dry matter intake, $\mathrm{kg}$ & $21.18^{\mathrm{a}}$ & $23.28^{\mathrm{b}}$ & $23.42^{\mathrm{b}}$ & 2.60 \\
Milk yield, kg/d & 37.43 & 36.31 & 36.67 & 2.24 \\
Fat-corrected milk, kg/d & $32.94^{\mathrm{a}}$ & $31.69^{\mathrm{ab}}$ & $30.69^{\mathrm{b}}$ & 1.94 \\
Milk fat, \% & $3.20^{\mathrm{a}}$ & $3.16^{\mathrm{ab}}$ & $2.97^{\mathrm{b}}$ & 0.60 \\
kg/d & $1.20^{\mathrm{a}}$ & $1.15^{\mathrm{ab}}$ & $1.09^{\mathrm{b}}$ & 0.15 \\
Milk protein, \% & 3.01 & 3.10 & 3.04 & 0.25 \\
kg/d & 1.13 & 1.12 & 1.10 & 0.17 \\
Lactose, \% & 4.95 & 4.94 & 4.98 & 0.22 \\
Urea N, mg/l & $224^{\mathrm{a}}$ & $229^{\mathrm{a}}$ & $200^{\mathrm{b}}$ & 36 \\
\hline
\end{tabular}

ab means in the same row with different superscripts differ $(\mathrm{P}<0.05)$

Table 4 presents data on the FA pattern of milk fat. Milk fat from cows fed diets supplemented with RC and EEC contained more stearic acid, vaccenic acid and CLA, and less palmitic acid than milk fat of cows fed the diet with $\mathrm{PPF}(\mathrm{P}<0.05)$. The PUFA concentrations were higher in the milk fat of cows fed ESB than in other cows. The atherogenicity of milk fat FA of the former cows was lower, and their peroxidisability, higher in comparison with the FA of cows fed PPF and RC. Supplementation of TMR with RC significantly increased the spreadability index by $26.9 \%$ against the control $(\mathrm{P}<0.025)$. 
TABLE 4. Fatty acid pattern ${ }^{1}$ of milk of cows fed diets supplemented with protected palm fat (PPF), rapeseed cake $(\mathrm{RC})$ and extruded soyabean $(\mathrm{ESB})$

\begin{tabular}{|c|c|c|c|c|c|}
\hline \multirow{2}{*}{\multicolumn{2}{|c|}{ Item }} & \multicolumn{3}{|c|}{ Diet } & \multirow[t]{2}{*}{ SEM } \\
\hline & & \multirow{2}{*}{$\begin{array}{l}\text { PPF } \\
1.36\end{array}$} & \multirow{2}{*}{$\begin{array}{r}\mathrm{RC} \\
1.41\end{array}$} & \multirow{2}{*}{$\begin{array}{l}\text { ESB } \\
1.44\end{array}$} & \\
\hline Caproic & (C 6:0) & & & & 0.24 \\
\hline Caprylic & (C 8:0) & 0.90 & 0.96 & 0.90 & 0.17 \\
\hline Capric & (C 10:0) & $2.06^{\mathrm{a}}$ & $2.46^{\mathrm{b}}$ & $2.09^{\mathrm{a}}$ & 0.51 \\
\hline Lauric & (C 12:0) & $2.79^{\mathrm{a}}$ & $3.05^{\mathrm{b}}$ & $2.76^{\mathrm{a}}$ & 0.57 \\
\hline Myristic & (C 14:0) & $10.18^{\mathrm{a}}$ & $11.13^{\mathrm{b}}$ & $10.44^{\mathrm{a}}$ & 1.17 \\
\hline Myristoleic & (C 14:1) & 1.08 & 1.04 & 1.13 & 0.50 \\
\hline Palmitic & (C 16:0) & $32.78^{\mathrm{a}}$ & $26.98^{b}$ & $28.82^{\mathrm{b}}$ & 2.69 \\
\hline Palmitoleic & (C 16:1) & $1.57^{\mathrm{a}}$ & $1.24^{\mathrm{b}}$ & $1.31^{\mathrm{ab}}$ & 0.46 \\
\hline Stearic & (C 18:0) & $9.98^{\mathrm{a}}$ & $12.69^{b}$ & $11.20^{\mathrm{ab}}$ & 2.30 \\
\hline Oleic & $(\mathrm{C} 18: 1 \mathrm{n} 9 \mathrm{c})$ & 25.54 & 26.59 & 25.30 & 2.72 \\
\hline Elaidic & (C 18:1 n 9t) & $0.84^{\mathrm{a}}$ & $0.97^{\mathrm{b}}$ & $0.91^{\mathrm{ab}}$ & 0.24 \\
\hline Vaccenic & (C 18:1 n 11t) & $0.44^{\mathrm{a}}$ & $0.53^{\mathrm{b}}$ & $0.54^{\mathrm{b}}$ & 0.07 \\
\hline Linoleic & (C 18:2 n 6) & $3.52^{\mathrm{a}}$ & $3.16^{\mathrm{b}}$ & $5.01^{\mathrm{c}}$ & 0.58 \\
\hline$\alpha$-Linolenic & (C 18:3 n 3) & $0.45^{\mathrm{a}}$ & $0.52^{\mathrm{ab}}$ & $0.69^{\mathrm{b}}$ & 0.08 \\
\hline CLA & (C 18:2 n 3) & $0.68^{\mathrm{a}}$ & $0.87^{\mathrm{b}}$ & $1.01^{\mathrm{c}}$ & 0.28 \\
\hline Arachidonic & (C 20:4 n 6) & 0.17 & 0.17 & 0.20 & 0.05 \\
\hline EPA & (C 20:5 n 3) & 0.04 & 0.05 & 0.04 & 0.01 \\
\hline DHA & (C 22:6 n 3) & 0.01 & 0.01 & 0.01 & 0.00 \\
\hline \multicolumn{2}{|l|}{ Other acids ${ }^{2}$} & $5.78^{\mathrm{a}}$ & $6.34^{\mathrm{b}}$ & $6.40^{\mathrm{b}}$ & 0.70 \\
\hline \multicolumn{2}{|l|}{$\Sigma \mathrm{SFA}^{3}$} & 62.23 & 60.14 & 60.04 & 3.56 \\
\hline \multicolumn{2}{|l|}{$\Sigma$ MUFA $^{3}$} & 30.64 & 31.83 & 30.67 & 3.13 \\
\hline \multicolumn{2}{|l|}{$\Sigma$ PUFA $^{3}$} & $5.88^{\mathrm{a}}$ & $5.85^{\mathrm{a}}$ & $8.07^{\mathrm{b}}$ & 0.89 \\
\hline \multicolumn{2}{|l|}{$\Sigma$ PUFA n- $3^{3}$} & $1.25^{\mathrm{a}}$ & $1.54^{\mathrm{a}}$ & $1.84^{\mathrm{b}}$ & 0.09 \\
\hline \multicolumn{2}{|l|}{$\Sigma$ PUFA n-6 ${ }^{3}$} & $4.36^{\mathrm{a}}$ & $4.05^{\mathrm{a}}$ & $6.02^{\mathrm{b}}$ & 0.63 \\
\hline \multicolumn{2}{|c|}{ PUFA n-6/n-3 } & $3.49^{\mathrm{a}}$ & $2.63^{\mathrm{b}}$ & $3.27^{\mathrm{a}}$ & 0.55 \\
\hline \multicolumn{2}{|c|}{ Index of atherogenicity ${ }^{4}$} & $2.09^{\mathrm{a}}$ & $1.98^{\mathrm{ab}}$ & $1.89^{\mathrm{b}}$ & 0.36 \\
\hline \multicolumn{2}{|c|}{ Index of peroxidisability ${ }^{4}$} & $8.69^{\mathrm{a}}$ & $8.84^{\mathrm{a}}$ & $11.33^{\mathrm{b}}$ & 1.04 \\
\hline \multicolumn{2}{|c|}{ Index of desaturation ${ }^{4}$} & 0.72 & 0.68 & 0.69 & 0.04 \\
\hline \multicolumn{2}{|c|}{ Index of spreadability ${ }^{4}$} & $0.78^{\mathrm{a}}$ & $0.99^{\mathrm{b}}$ & $0.88^{\mathrm{ab}}$ & 0.17 \\
\hline
\end{tabular}

${ }^{1}$ expressed in $\mathrm{g}$ per $100 \mathrm{~g}$ of fatty acids determined

${ }^{2}$ twenty-two minor C 11 - C 24 fatty acids (see www.vuzv.cz/vyziva/krmeni/kudrna.htm)

${ }^{3}$ including relevant minor fatty acids

${ }^{4}$ see Material and Methods for explanation

abc means in the same row with different superscripts differ $(\mathrm{P}<0.05)$

\section{DISCUSSION}

Dietary supplementation with RC and ESB improved the FA profile of milk fat of high-yielding cows. Inclusion of RC and ESB into TMR led to a higher proportion of total PUFA of the n-3 series, CLA, and its precursor, vaccenic 
acid. The effect of ESB on total PUFA, PUFA n-3 and CLA concentrations was more pronounced than that of RC. Our findings are in agreement with the data of other authors. Strzetelski et al. (1998), McNamee et al. (2002) and Givens et al. (2003) reported that feeding cows with rapeseed significantly enhanced the oleic and stearic acid contents in milk fat at the expense of $\mathrm{C} 8$ to $\mathrm{C} 16$ saturated FA. Similarly, Nowak and Potkański (2000) reported that feeding rolled rapeseed increased the concentration of oleic acid in milk fat at the expense of short- and medium-chain FA, i.e. FA predominantly synthesized in the mammary gland. Schauff et al. (1992) observed that supplementation of a diet for dairy cows with whole soyabean increased the percentages of long-chain FA in milk fat, whereas the percentages of short-chain and medium-chain FA were lower. Feed intake, milk yield, and yield of the main milk constituents were not affected.

The beneficial effects of CLA are very well known (review by Belury, 2002). The major CLA, cis-9, trans-11 CLA, is synthesized either in the rumen as an intermediate in the biohydrogenation of linoleic and linolenic acids, or in the mammary gland from vaccenic acid by $\Delta 9$-desaturase. Human tissues also have a $\Delta 9$-desaturase activity and convert vaccenic acid into CLA (Salminen et al., 1998). The increased concentration of vaccenic acid in milk fat may thus be beneficial for human health, despite its belonging to trans-FA, which are harmful to human health (Stender and Dyerberg, 2004). Positive effects of feeding oilseeds and oilseed-based supplements on the CLA and vaccenic acid contents in milk fat were also observed by other researchers (review by Chilliard and Ferlay, 2004). The index of FA atherogenicity decreased in the milk fat of cows fed the RC and ESB diets, in the former cows a tendency was observed, in the latter cows, the decrease was significant $(\mathrm{P}<0.05)$, mainly due to a significant reduction of the palmitic acid content. The oxidative stability of milk fat from cows fed ESB, however, worsened. The oilseed-based supplements also resulted in a lower ratio of oleic and palmitic acid, which would be indicative of a softer, more spreadable butter.

Cows fed the PPF diet consumed significantly less TMR dry matter than cows on the RC and ESB diets. Consequently, in these cows (with the highest milk yield) body weight remained stable, whereas in cows fed RC and ESB, it increased in the course of the trial. The concentration of milk fat was rather low in all cows, probably because of the high consumption of concentrates ( 9 to $10 \mathrm{~kg} / \mathrm{d}$ ) and negative effect of lipids on digestion of fibre (Szumacher-Strabel et al., 2000). Concentrations of milk urea were higher than those reported by Hof et al. (1997), but lower than values reported by Komprda et al. (2000). A close correlation exists between the rumendegraded protein balance in the ration and the urea concentration in milk (Schepers and Meijer, 1998). Crude protein of ESB is thus less degradable in the rumen than crude protein in PPF and RC supplemented diets. It can be concluded that feeding 
oilseed supplements decreased milk yield and milk production efficiency, but significantly improved the nutritional quality of milk fat.

\section{REFERENCES}

Belury M.A., 2002. Dietary conjugated linoleic acid in health: physiological effects and mechanisms of action. Annu. Rev. Nutr. 22, 505-531

Castellini C., Dal Bosco A., Bernardini M., 2000. Improvement of lipid stability of rabbit meat by vitamin $\mathrm{E}$ and $\mathrm{C}$ administration. J. Sci. Food Agr. 81, 46-53

Chilliard Y., Ferlay A., 2004. Dietary lipids and forage interactions on cow and goat milk fatty acid composition and sensory properties. Reprod. Nutr. Develop. 44, 467-492

Chouinard P.Y., Girard V., Brisson G.J., 1997. Performance and profiles of milk fatty acids of cows fed full fat, heat-treated soybeans using various processing methods. J. Dairy Sci. 80, 334-342

Gajdůšek S., Jelínek P., Hampl A., 1996. Somatic cell counts in goat milk and their relation to milk composition and properties. Živoč. Výr. 41, 25-31

Givens D.I., Allison R., Blake J.S., 2003. Enhancement of oleic acid and vitamin E concentrations of bovine milk using dietary supplements of whole rapeseed and vitamin E. Anim. Res. 52, 531-542

Hof G., Vervoorn M.D., Lenaers P.J., Tamminga S., 1997. Milk urea nitrogen as a tool to monitor the protein nutrition of dairy cows. J. Dairy Sci. 80, 3333-3340

ISO 1211: Milk-determination of fat content - gravimetric method (reference method)

ISO 5509: Animal and vegetables fats and oils. Preparation of methyl esters of fatty acids

Komprda T., Dvořák R., Suchý P., Fialová M., Šustová K., 2000. Effect of heat-treated rapeseed cakes in dairy cow diet on yield, composition and fatty acid pattern of milk. Czech J. Anim. Sci. $45,325-332$

McNamee B.F., Fearon A.M., Pearce J., 2002. Effect of feeding oilseed supplements to dairy cows on ruminal and milk fatty acid composition. J. Sci. Food Agr. 82, 677-684

Nowak W., Potkański A., 2000. The effect of rolled rape seeds on milk composition and lactational responses. J. Anim. Feed Sci. 9, 425-434

Salminen I., Mutanen M., Jauhiainen M., Aro A., 1998. Dietary trans fatty acids increase conjugated linoleic acid levels in human serum. J. Nutr. Biochem. 9, 93-98

Schauff D.J., Elliot J.P., Clark J.H., Drackley J.K., 1992. Effects of feeding lactating dairy cows diets containing whole soybeans and tallow. J. Dairy Sci. 75, 1923-1935

Schepers A.J., Meijer R.G.M., 1998. Evaluation of the utilization of dietary nitrogen by dairy cows based on urea concentration in milk. J. Dairy Sci. 81, 579-584

Stender S., Dyerberg J., 2004. Influence of trans fatty acids on health. Ann. Nutr. Metab. 48, 61-66

Stern M.D., Santos K.A., Satter L.D., 1985. Protein degradation in rumen and amino acid absorption in small intestine of lactating dairy cattle fed heat-treated whole soybeans. J. Dairy Sci. 68, 45-56

Strzetelski J.A., Kowalczyk J., Krawczyk K., Stasiniewicz T., Lipiarska E., 1998. Evening primrose (Oenothera paradoxa) oil cake or ground rape seed supplement to diets for dairy cows. J. Anim. Feed Sci. 7, 365-375

Szumacher-Strabel M., Cieślak A., Potkański A., 2000. A note on the effect of diet and type of fat on cellulose degradability in the rumen of sheep. J. Anim. Feed Sci. 9, 527-532

Timmen H., 1990. Characterization of milk fat hardness in farm milk by parameters of fatty acid composition. Kiel. Milchwirt. Forschungsber. 42, 129-138

Van Soest P.J., Robertson J.B., Lewis B.A., 1991. Methods for dietary fiber, neutral detergent fiber, and non starch polysaccharides in relation to animal nutrition. J. Dairy Sci. 74, 3583-3597 